\title{
Citation:
}

De Waele, M. Pauwels, L. (2016). Why do Flemish youth participate in right-wing disruptive groups. In: Maxson, C., Esbensen, F. (Eds). Gang Transitions and Transformations in an International Context, New York: Springer.

\section{Why do Flemish youth participate in right-wing disruptive groups}

Maarten De Waele

Lieven Pauwels

The events of 9/11 gave rise to an increase in studies on political violence and terrorism. Horgan (2005), Bouhana \& Wikström (2010) postulated that the increase in publications has not led to an increase in empirical studies of pull and push factors of participation in extremist groups. Horgan argues that theoretical cloudiness around the concepts of extremism and terrorism impedes our understanding of the phenomenon and its causes. Some scholars have, however, attempted to integrate fragmented knowledge in a theoretical framework. The present inquiry builds upon insights derived from theoretical and empirical contributions regarding the participation in gangs and violent extremist groups to propose an integrative framework useful for studying participation in right-wing disruptive groups. To test the integrated model, a series of SEM models were run for testing the strength of direct and mediator effects of perceived injustice, anomia, authoritarianism and thrill-seeking behaviour. We test to what extent feelings of superiority, Flemish nationalism and ethnocentrism mediate these effect and have consequences for moral support for right-wing extremism, exposure to racist peers and participation in right-wing disruptive groups. The analyses are based on a web survey $(N=723)$ among adolescents and young adults in Flanders, Belgium.

Key words: Perceived injustice, right-wing extremism, disruptive participation, thrill-seeking behaviour, moral support for right-wing extremism

\section{Introduction}

Gang research has a long and outstanding tradition in criminological inquiries (Decker and Weerman, 2005; Klein and Maxson, 2006; Esbensen and Maxson, 2011). While the study of troublesome youth groups in Belgium is still limited in comparison to other countries in Europe such as The Netherlands (Esbensen and Weerman, 2015), there is a growing interest 
in the topic in Belgium (Pauwels, et al., 2011; Pauwels \& Svensson, 2013; Van Hellemont, 2013; Vettenburg et al., 2013). Studies on participation in right-wing extremist groups are currently lacking in Belgium. Therefore, the present study aims at filling this gap by testing an integrative model of participation in right-wing extremist groups. Qualitative studies on neoNazi gangs and racist groups have supplied us with detailed information concerning motives for entry (Bjørgo, 2002; Sela-Shayovitz, 2012). In contrast, this contribution will analyse the role of social-psychological mechanisms on participation in right-wing extremist groups. Previously, Bouhana and Wikström (2010) argued that studies of terrorism and violent extremism suffer from a poor understanding of causal mechanisms and lacking integration of explanatory levels. Bouhana and Wikström were not alone with criticism, a comparable statement was made earlier by Mudde (2002: 10) on the state of the art of studies on rightwing extremism: ${ }^{1}$ here Mudde argued that this lack of knowledge“ [...] has been partly caused by the fact that the term is not only used for scientific purposes but also for political purposes.". The social construction of this politically sensitive concept is shaped by multiple actors, such as politicians, academics and the media. Although the debate is interesting and in need for clarification from a criminological point, the presents study does not aim at extending the debate on the best definition of right-wing extremism: The focus is on presenting and testing an integrative model that integrates elements from social psychological and sociological traditions that have previously been applied to the study of violent youth groups. In fact, as Decker and Pyrooz (2015) have correctly argued: there is a lot to learn from 100 years of gang research when testing theories of violent extremism. This study can be seen as a modest attempt to do so.

Between November 2012 and April 2013, an online survey ( $\mathrm{N}=723)$ was conducted among Flemish students. The aim of the questionnaire was to test a self-designed conceptual model explaining right-wing disruptive participation. First, we provide an outline of the integrated framework that has been used, second, we discuss the data, sample and methods used, and third, we present the results of path analyses. Finally, the findings are discussed.

\section{The historical roots of Flemish nationalism}

\section{Support for right-wing extremism among Flemish nationalists}

\footnotetext{
${ }^{1}$ For more detail on the definition of right-wing extremism, see: De Waele, M. (2013). Flemish youngsters and right-wing extremist groups. Status quaestionis. In A. Crawford, J. de Maillard, J. Shapland, A. Verhage \& P. Ponsaers (Eds.), Crime, violence, justice and social order. Monitoring Contemporary Security Issues (pp. 15-41). Antwerpen/Apeldoorn/Portland: Maklu.
} 
Belgium is a small country, with a complex political structure. To understand the roots of nationalism it is important to provide some information on the historical context. Historical studies reveal that, right-wing sympathies in Belgium have always been routed within Flemish nationalist circles. This is due to the fact that historically, the political elite of Belgium was French, French was the language of the elite and the Flemish language and people were suppressed. Right from the founding of Belgium, some groups fought for oppressed Flemish people and rights for the Flemish language. These sentiments were even further strengthened due to the events in the First World War, where narratives indicate that Flemish soldiers were subjected and often humiliated by Francophone commanders (Boijen, 1998). During the interwar period, anti-Belgian and Flemish nationalist translated into far-right extremist groups such as Verdinaso and Vlaams Nationaal Verbond (VNV-Flemish National Pact). Although the collaboration generated a stigma on right-wing Flemish nationalist, in contrast to Wallonia, repression was mainly considered out of dissatisfaction with the Belgian state. Rather than cooperation with the Nazi regime, motives were attributed to identification with Flemish nationalist feelings. This led to opportunities for Flemish movement to re-establish a political movement concentrating on the amnesty requirements for the Flemish collaborators. Out of this Flemish emancipation movement grew, since the end of the seventies, a more radical right-wing political party (i.e. Vlaams Blok-Flemish Interest), which gradually build out their grassroots. It is within the latter timeframe that public and political agenda was strongly determined by migration issues, leading to a breakthrough of the right-wing parties in Western-Europe (Front National in France, Centrum Democraten in the Netherlands and FPÖ in Austria) (Coffé, 2005). In Flanders, this breakthrough even led to a growth of the electorate of the Vlaams Blok to almost a quarter of the votes of the Flemish people in 2004 (24, 2\%). Due to resistance of other parties, Vlaams Blok never succeeded to convert electoral support into government participation. Recently, the electoral support of the party has dropped to a marginal level of approximately 5\%. However, the support has indicated that there is to some extent a breeding ground for extreme right-wing views and an anti-immigrant discourse.

Although there is close overlap between Flemish nationalism and support for a right-wing ideology, it is clear that one does not imply the other. Flanders, for instance, currently deals with some, mostly right-wing national solidarist groups, who tend to focus less on the subnational context but more on geopolitical issues. Vice versa, there are also Flemish nationalist movements, without political orientation aiming to gather a broad Flemish public 
regarding linguistic and cultural matters. In that sense it can be argued that national and subnational identity are constructions, who are by no means static, but rather vary across different levels (national, subnational, local) and depend on the occurrence of diverse situations. Recently the German case of HoGeSa (hooligans against Salafist) illustrated the relativeness of constructed identities. During demonstrations of the HoGeSa group, hooligans, supporting rival football teams, set aside their hatred for each other in order to form a coherent group against a common Salafist enemy. Likewise Michael (2006) noted convergence between Islamic militant groups and extreme-rights groups, combatting common Jewish enemies. Tajfel and Turner (1974) worked on the influence of social identity and indicated that shared experiences, values and norms of the group are crucial for the development of social identity and status of the group in relation to enemies. They refer to the social-psychological process of in-group socialisation when individuals enter a certain group. The cited examples indicate the relativeness of in-group construction. On the other hand, not only a positive identification, but also a negative identification towards the 'out-group' (contra-identification) needs to be mentioned. It is this negative component which reinforces in-group socialisation and ethnocentric worldviews of group members.

This contribution wants to elaborate on previous work by testing direct and indirect effects of mechanisms involved in participation of Flemish right-wing disruptive in-groups. Goodwin, Ramalingan and Briggs (2012) developed a typology of extreme-right political groups ${ }^{2}$;, i.e. political parties, social movements and subcultural networks. First, there are the political parties who want to shape public policy through elected members. In this category, members might be linked to violent acts or criminality, but parties themselves will strive to operate, at least to the outside world, within the legal framework of the legislation. Second, in contrast to the party-political group, social movements are not politically active within the parliamentary decision making process. However, they are still active on political issues such as migration, independence and linguistic matters. Finally, the subcultural networks do not tend to shun violence and relations are built on respect and kinship (Bjørgo, 1997; Sela-Shayovitz, 2011). It is here that neo-Nazi gangs come into play. Referring to Maxson and Klein's (1995) gang typology, the latter group might be considered to be a small informal 'speciality group'. This research explores the theory-driven mechanisms that distinguish individuals who are involved in a right-wing disruptive group versus those not involved.

\footnotetext{
${ }^{2}$ Goodwin et al. also indicated a fourth category of lone wolves. However, in this contribution we only focus on participation in right-wing politically engaged groups.
} 


\section{An integrative mechanism-based approach}

The idea in criminology that a single theoretical framework does not provide a salient explanation for offending and for participation in troublesome youth groups has long since been acknowledged. Elliott, Ageton, and Canter (1979) indicated already in the late seventies that theoretical reliance on variables from one theory (cf. strain, self-control, etc.) for the explanation of offending have limited results considering the moderate level of explanatory power for crime or criminal behaviour. Furthermore, competitive testing of theories on criminal behaviour did not lead to yield conclusive results (Bernard \& Snipes, 1996; Liska, Krohn \& Messner, 1989). However, integration does not come without restrictions. Thornberry (1989) warns scholars about creating theoretical mush by which the fundamental purpose of theory constructions is neglected. Scholars should not focus much on differences, but rather discover communalities in seemingly competing theories. It is emphasized that integration should built on an internal causal logic to explain phenomena. Integrated theories need to take causation, human agency and the person-environment interaction more seriously to advance knowledge, causes and preventive actions. This implicates that it is important to not only gain insights into the direct causes of participation but additionally into what can be referred to as 'the causes of the causes' or the remote causes of participation in a disruptive group (Wikström, 2010).

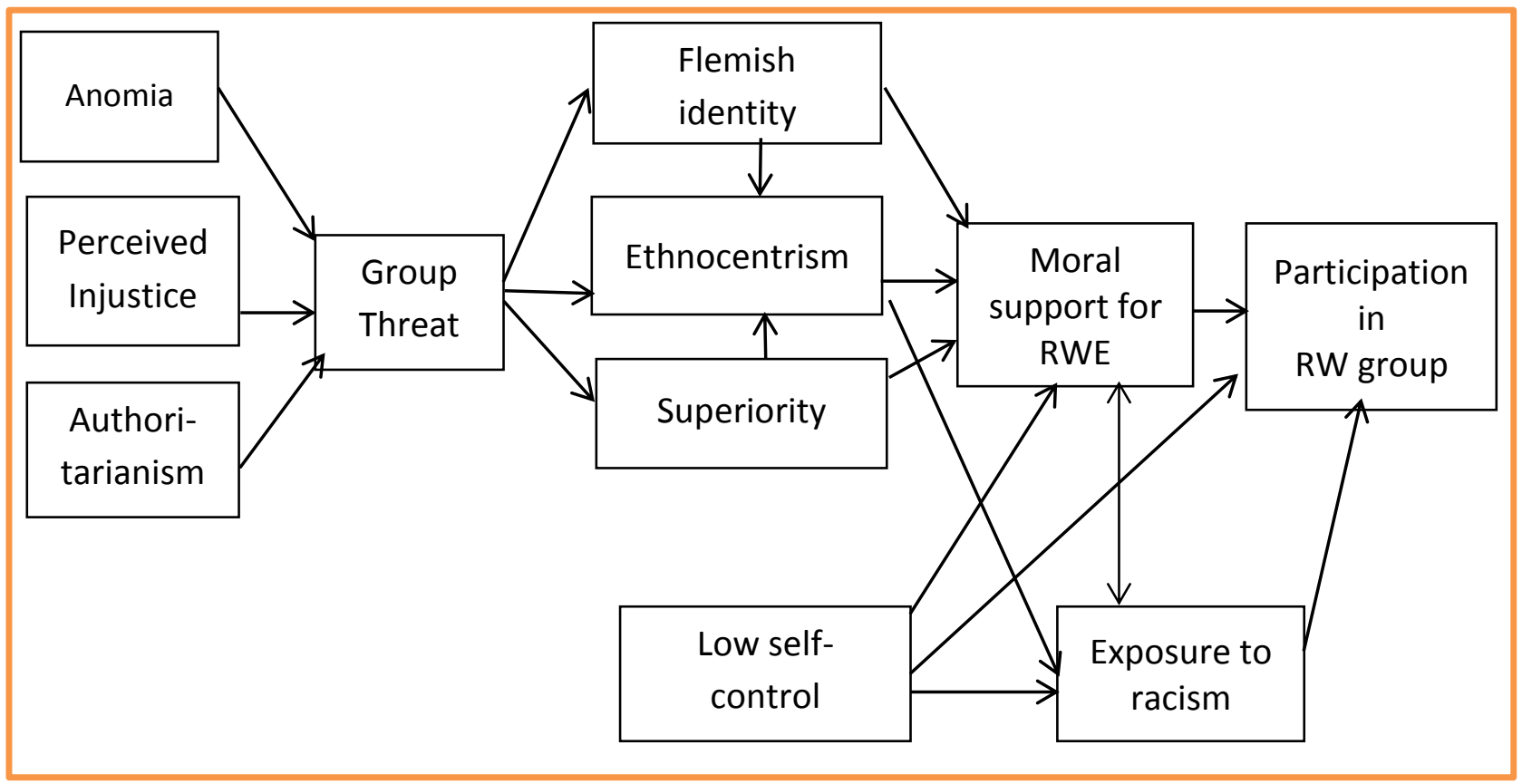

Fig. 1 Conceptual model for the explanation of right-wing disruptive participation 


\section{Strain initiated model}

Studies of political violence have repeatedly drawn attention to channels of inequality and injustice. Within the field of criminology, it has especially been the merit of Agnew's general strain theory to stress the importance of perceived injustice. Agnew's General Strain Theory (GST) argues that negative feelings may cause strain, which can pressure adolescents into crime (by stimulating negative emotions and violent beliefs) (Agnew, 2006, 2011). Subjective strains, such as perceived injustice, and feelings of political powerlessness (anomia) may act as stressors that may trigger one's involvement in political violence, especially through the impact on moral support for political violence as an intermediate mechanism.

Perceived injustice corresponds to the idea that one's own group is unjustly disadvantaged in comparison to other groups in society and/or the feeling of being treated unfairly by society. It is not objective discrimination or injustice that is important, but rather the subjective perception and experience of it.

\section{Anomia}

Runciman (1966) first introduced the term of relative deprivation in his study on attitudes of social inequality and in that way inspiring Gurr (1970) to operationalize the concept as a state of deprivation by which persons compare their own situation with those of others. Therefore, anomic people are often seen as helpless, alone, powerless and disintegrated from society. A study of Doosje, Loseman, van den Bos (2013) and a study conducted by Pauwels et al. (2014) indicated that perceived injustice, perceived discrimination and alienation were strong predictors of moral support for the use of violence by terrorist groups, which in turn was a strong mediator for self-reported political violence.

\section{Authoritarianism}

In 'The Authoritarian Personality', Adorno and colleagues (1950) developed the concept of authoritarianism as a relatively stable intrapersonal trait which results from enduring intrapersonal conflicts rooted in childhood experiences of harsh education. Adorno argued that authoritarians consider others - out of dissatisfaction with their own position - as weak or immoral (Adorno et al., 1950; Whitley \& Ægisdóttir, 2000). Altemeyer (1998) neglected the idea of authoritarianism as an intrapersonal characteristic and believed that authoritarianism consists of a set of coherent attitudes which is learned from peer groups and similar socialising agents (Altemeyer, 1981, 1988). Altemeyer reconceptualised authoritarianism as a value syndrome that comprises three distinct elements: (1) conventionalism, which is a high 
level of compliance with social norms; (2) an emphasis on hierarchy and submission to authority; and (3) a 'law and order' mentality which legitimises anger and aggression against those who deviate from social norms. Authoritarians are often supporters of nationalism and share ethnocentric attitudes.

Authoritarianism, anomia, and perceived injustice have consequences for perceptions of group threat.

\section{Perceived group threat}

Researchers often indicate strong effects of group threat toward prejudice of out-groups. Manifestations of prejudice is explained as coping mechanism to establish group privilege (Blumer, 1958). In their experiment on threatening information about ethnic out-groups, Cohrs and Ibler (2009) indicated that high levels of right-wing authoritarian (RWA) feelings increased the likelihood of prejudicial attitudes. Perceptions of threat may endorse people to engage in violent activities to restore feelings of anxiety and threat. Three dimensions of perceived threat have been identified in the literature (Stephan et al, 2002, Doosje et al, 2013), i.e. symbolic threat, realistic threat and intergroup anxiety. The first refers to the threat towards the respondents culture. Translated to our study, a threat toward the Flemish/Belgian culture. Realistic threat, on the other hand, refers to economic conditions and the influence of immigrant groups. Quillian (1995) indicated in his study that threat is perceived by individuals, but the effect on prejudice is largely grounded on the context of intergroup relations between dominant and subordinate social group. Ethnocentrism is defined as negative attitudes towards the out-group. This 'in-/out-group' relation allows people to break down the barriers of illegality (Heitmeyer, 2003; Van der Valk and Wagenaar, 2010).

Perceived group threat is hypothesized to be of indirect importance to participation in a right-wing extremist group through its effect on Flemish identity, ethnocentrism and feelings of superiority.

\section{Flemish identity and Superiority}

A strong Flemish identity is often equated with right-wing militancy. Nevertheless, this relationship can by no means be seen as a causal relationship. Pennings and Brants (1985) state in their research that right-wing extremism is characterised by strong anti-leftist opinion because of its supporters' rejection of multiculturalism and internationalism. Extreme rightwing groups are seeking instead to promote their own Flemish nationalistic in-group. This form of nationalism is often associated with feelings of superiority towards the Flemish 
people or the so-called superior race. Results from Scandinavian research on former members of extreme right wing groups have indicated that various extremists were convinced that they belonged to a superior group (Kimmel, 2007).

\section{Moral support for right-wing extremism}

The concept of moral support for right-wing extremism refers to the individual's positive attitude towards the use of violence by right-wing extremist groups. Radicalisation is often defined as the process whereby individuals acquire a moral support for violence used in a means-to-an-ends fashion. Moral support for right-wing extremist violence constitutes a personal moral belief that favours the use of violence by right-wing extremist groups. In the perceived injustice induced model, moral support for violence is seen as the key mechanism by which perceived injustice, group threat, authoritarianism, anomia, feelings of superiority, Flemish identity and ethnocentrism translate into right-wing disruptive group participation. A multitude of studies have found that measures of antisocial moral beliefs are significantly related to offending (Bottoms 2002; Hirschi 1969; Stams et al. 2006; Svensson, Pauwels, and Weerman 2010; Antonaccio and Tittle 2008) and political violence (Hagan, Merkens and Boehnke, 1995; Pauwels and De Waele, 2014).

\section{Thrill-seeking behaviour}

While the perceived injustice model is of considerable interest, it is silent on the role of selfcontrol. While self-control theory was not originally developed to explain individual differences in right-wing extremist groups, Hirschi and Gottfredson claimed their theory was a general theory of crime.

The central assumption in Gottfredson and Hirschi's (1990) General Theory of Crime is that low self-control increases the risk of offending, as well as other deviant and imprudent behaviours. A large number of studies have tested this proposition and empirical research shows that low self-control is associated with offending among different samples (e.g. youth, college students, adults, males vs. females, criminals) and in different designs (Burton, Cullen, Evans, Alarid, \& Dunaway, 1998; Pratt \& Cullen, 2000). More recently attention has been paid to the concept of self-control in the explanation of troublesome youth group involvement (Kissner \& Pyrooz, 2009; Esbensen \& Weerman, 2005; Hope \& Damphousse, 2002). Therefore it is an importance question to test empirically whether thrill-seeking behaviour is an additional mechanism that exerts an independent effect on right-wing disruptive group participation. Ethnographic studies have indicated that new members are 
often motivated out of own opportunistic or thrill-seeking motives (Bjørgo, 2002; Watts, 2001). Although ideological motivations are important in understanding acts of politically motivated violence, ideology is not always crucial for entering extremist groups. The search of adventure, i.e. thrill-seeking behaviour is one of the reasons often mentioned by (former) members of extremist groups.

A pure self-control-based explanation would consider self-control to be the ultimate cause of right-wing extremist group involvement. Moral support for right-wing extremism, exposure to racist peers and participation in a right-wing extremist group would therefore all be common consequences of low self-control.

\section{Exposure to racist peers}

The role of peers is especially prominent in social learning theories (Akers, 1998; Bruinsma, 1992; Warr, 2002) but highly contested in control theories (Hirschi \& Gottfredson, 1990; Kornhauser, 1978; Hirschi, 1969). Peer delinquency is one of the strongest predictors of selfreported delinquency, therefore, it is expected that this also applies to the study of right-wing extremist group participation. Differential association with racist and/or delinquent peers provide two specific contexts of exposure to settings in which the use of violence either in general or for political reasons is supported. Differential associations are not only important in social learning theory, however, but also in routine-activities/lifestyle theory (Laub \& Sampson, 2003; Wikström and Butterworth, 2006; Pauwels \& Svensson, 2013). From a routine activities/lifestyle perspective peers are important as they may be responsible for the situational instigation to commit an act of (political) violence or becoming involved in a rightwing extremist group. In the present study we take into account exposure to peer racism as important indicator of exposure to criminogenic moral settings, shaping the individual's routines and risky lifestyle.

To test the conceptual model that has been outlined above, a series of hypotheses are tested:

- Group threat is determined by authoritarianism, anomia and perceived injustice;

- Flemish identity, ethnocentrism and superiority are determined by group threat;

- Moral support for right-wing extremism is determined by superiority, Flemish identity, ethnocentrism and thrill-seeking behaviour;

- Exposure to racist peers is directly related to thrill-seeking behaviour, ethnocentrism and moral support for right-wing extremism; 
- Participation in a right-wing disruptive group is directly related to moral support for right-wing extremism, exposure to racist peers and thrill-seeking behaviour.

\section{Data and method}

\section{Participants}

Data was collected through a web survey of adolescents and young adults between the age of 18 and 25. During this period the youngster is confronted with both bodily and mental changes. Research has indicated that participation is often part of taking a first step towards adulthood. During this period adolescents are confronted with newly legal situations (e.g. use of alcohol, cigarettes, becoming an sexual active adult, etc.). These transitional events are often referred to as a form of symbolic 'rite of passage' (Hodkinson and Deicke, 2007; Kimmel, 2007). In comparison to elderly people, the mind-set of youngsters is often less nuanced and more divided into a strict separation of right and wrong. The present study is not only limited to the aforementioned age category, but also to the Flemish youth who live in Flanders, have the Belgian nationality and parents with the Belgian nationality.

The web survey consists of a self-administered questionnaire that was conducted online between December 2012 and April 2013 and let to a response of 723 respondents. A majority of those respondents were female (64.3\%), student (94.7\%) and where either Catholic $(45.6 \%)$ or atheist $(47.3 \%)$. Only $0.4 \%$ (3 respondents) were unemployed and $3.2 \%$ of the youngsters indicated that they had a job. In terms of geographical spread, we note that the whole region of Flanders was surveyed. The majority of people where from the eastern part of Flanders, with respectively 34.7 and $29.3 \%$ of the respondents derived from the province of Limburg and Antwerp. The other respondents live in one of the other three provinces, Flemish Brabant and Brussels Capital (10.1\%), East Flanders (16.7\%) and West Flanders (9.3\%). Questions on political association, revealed that out of the $27.3 \%$ of the respondents who felt associated with a Flemish nationalist parties (i.e. N-VA or Vlaams Belang) only 2.5\% associated with the Flemish nationalist and extreme-right party Vlaams Belang ${ }^{3}$. 16 respondents $(2.2 \%)$ indicated to listen to right-wing inspired music, namely oi!, nazi-punk, rock against communism or white power music.

\footnotetext{
${ }^{3}$ Vlaams Belang is the successor of the formerly mentioned extreme-right party Vlaams Blok. The latter were later on convicted for their racist propaganda. After that incident they decided to continue their activity under the name Vlaams Belang, translated 'Flemish interest'
} 


\section{Data collection}

In this study we opted to use an online web survey since it requires little time and costs. On the other hand, however, this approach ensures that researchers cannot completely monitor the processes of response selection and the condition of the questionnaire cannot be verified completely (presence of others, anonymity, etc.). The motivation to participate is left entirely to the respondent and, therefore, data could have a selection bias. The impossibility of monitoring response selection, self-selection, and under-coverage (internet availability) are important to take into account. However, it should be mentioned that these drawbacks (preparedness to answer survey questions, willingness to report) are central to the more traditional survey modes as well. Furthermore, It is fair to state that web surveys contribute more to explanatory research (studies of the causes and correlates), rather than studying the prevalence of the phenomenon due to the lack of randomization. Scholars need to bear in mind that this approach only works if enough respondents indicate activity of the dependent variable. In the current study 30 respondents $(4.1 \%)$ scored positive on both right-wing sympathies and participation in a disruptive group. These proportions allow us to make reliable statistical claims about this group.

\section{Measurement of constructs}

In the present study numerous scale constructs were used to assess the relation between exogenous variables, mediators and dependent variables. In view of the extensive nature of concepts used in the present empirical study, a brief overview of the scale constructs is presented. Readers can find a more detailed overviews of the scales in appendix 1, which includes question wording and additional factor loadings per item for each scale.

\section{Dependent variable}

Right-wing disruptive group participation was measured using a funnelling technique, i.e. we combined answers to one filter question and four follow-up questions to measure self-reported VYG participation. The leading question was "Do you consider yourself to be a member of a group of friends (no organisation or association) that frequently meets and considers itself as a 
group?" ( 1 = yes, $0=$ no). The four follow-up questions were (1) How long have you been a member of the group? (2)How big is your group? (3) "Do members of this group get involved in fights with other cliques?" (4) "Are members of this group involved in law-breaking?". We decided to restrain those respondents who were member of a group for more than three months and with a group size of 3 or more persons. The last two questions were dichotomies ( 1 = yes, $0=$ no). Respondents were categorised as involved in a 'disruptive group' if they answered affirmatively to the leading question as well as to the four follow-up questions. To the introductory question $(n=295), 40.8 \%$ of the total sample answered positively, while $(n=$ 70), $9.7 \%$ of the total sample answered positively to the follow-up questions. From the latter proportion 30 respondents $(4.1 \%)$ identified themselves as (extreme-)right. Cronbach's alpha is 0.36 and the scale is derived from the Eurogang questionnaire (Pauwels and Svensson, 2013).

\section{Exogenous and independent variables}

Procedural justice refers to the way that one feels treated by others. Cronbach's alpha is 0.87 . Perceived personal discrimination refers to the feelings that one is discriminated in comparison with other people in society. Alpha is 0.78. Perceived group discrimination refers to discrimination of the group to which the respondent belongs. Cronbach's alpha is 0.90 . The items were originally used in a Dutch survey of attitudes towards extremism conducted by Doosje et al. (2013) and validated in a study of Pauwels and Schils (2014).

In the present study, a number of attitudes/beliefs that intervene in the relationship with perceived injustice are studied. These intervening mechanisms are authoritarianism, anomia, ethnocentrism, Flemish identity, superiority and thrill seeking behaviour. Authoritarianism was measured by using 11 items based on the three elements of Altemeyer's authoritarianism scale (conventionalism, hierarchy and submission, and law and order mentality). The Cronbach's alpha of the general authoritarianism scale is 0.83 . Ethnocentrism measured on the basis of the negative attitude towards the out-group (in this case migrants). The scale was derived from the SCIV questionnaire. Conbach's alpha is 0.88. Anomia (perceived political powerlessness) is derived from Srole's (1956) study of personal alienation. Cronbach's alpha is 0.87. Hirschi and Gottfredson's (1990) conceptualisation of self-control was used in the present study: thrill-seeking behaviour (the tendency to seek adventure and kicks). The items were taken from the attitudinal self-control scale used by Bursik and Grasmick (1993). This 
scale has been frequently used in the European Social Survey. Superiority was measured via two scales. The first measured the personal superiority, where one perceives himself as better than others. Cronbach's alpha of the personal scale is 0.81 . The other scale is related to group superiority and is in this case related to Flemish superiority. Alpha is 0.86 . This scale was derived from the superiority scale of Doosje et al. (2013) and adapted to the Flemish context. The overall concept of superiority gives a Cronbach's alpha of 0.85. The scales of Flemish identity and Perceived group Threat were also derived from the study of Doosje et al. (2013) and adapted to the Flemish context. Cronbach's alphas are respectively 0.87 and 0.92 . Moral support for right-wing extremism was measured using items from a scale that measures attitudes towards the use of violence by right-wing extremists in order to reach political goals. Cronbach's alpha is 0.87 . The items were taken from a larger scale used in a study by Doosje et al. (2013). Pro racist attitudes of peers is measured via the scale from Doosje et al. (2013). Cronbach's alpha is 0.85 . Finally, Peer delinquency refers to respondents' perception of lawbreaking behaviour by their best friends. This scale originates from the PADS+ study (Ceccato and Wikström, 2012). Cronbach's alpha is 0.74.

\section{Analysis plan}

To test the integrated theoretical model a series of path analyses were run. Path analysis allows testing of direct and indirect effects. As the dependent variables are dichotomous, a logistic path model was tested using Mplus (Muthén and Muthén, 2012). The results are shown in figure 2. Direct effects are presented. The direct relationships between the independent variables and right-wing disruptive group participation are log-odds and should be interpreted as the increase in the log-odds of the dependent variable as the independent variables increases with one unit. The relations between the interdependent scale variables were standardized before the analyses and presented through standardized path coefficients.

\section{Results}

In this section the results of the best fitting model are discussed. As hypothesized, anomia ( $\beta=$ $0.16)$, perceived injustice $(\beta=0.179)$ and authoritarianism $(\beta=0.631)$ are directly related to perceived group threat. There is a direct path from perceived group threat to Flemish identity ( $\beta=0.459)$, ethnocentrism (0.326) and feelings of superiority $(\beta=0.507)$. Moral support for right-wing extremism is directly related to ethnocentrism $(\beta=0.326)$, superiority $(\beta 0.145)$ and thrill-seeking behaviour $(\beta=0.194)$. Contradictory to what we expected, here is no direct 
path from Flemish identity to moral support. The effect is entirely mediated by ethnocentrism. Flemish identity has an independent effect on ethnocentrism $(\beta=0.171)$. There is no relationship between ethnocentrism and superiority. Perceived group threat has been identified as a common cause.

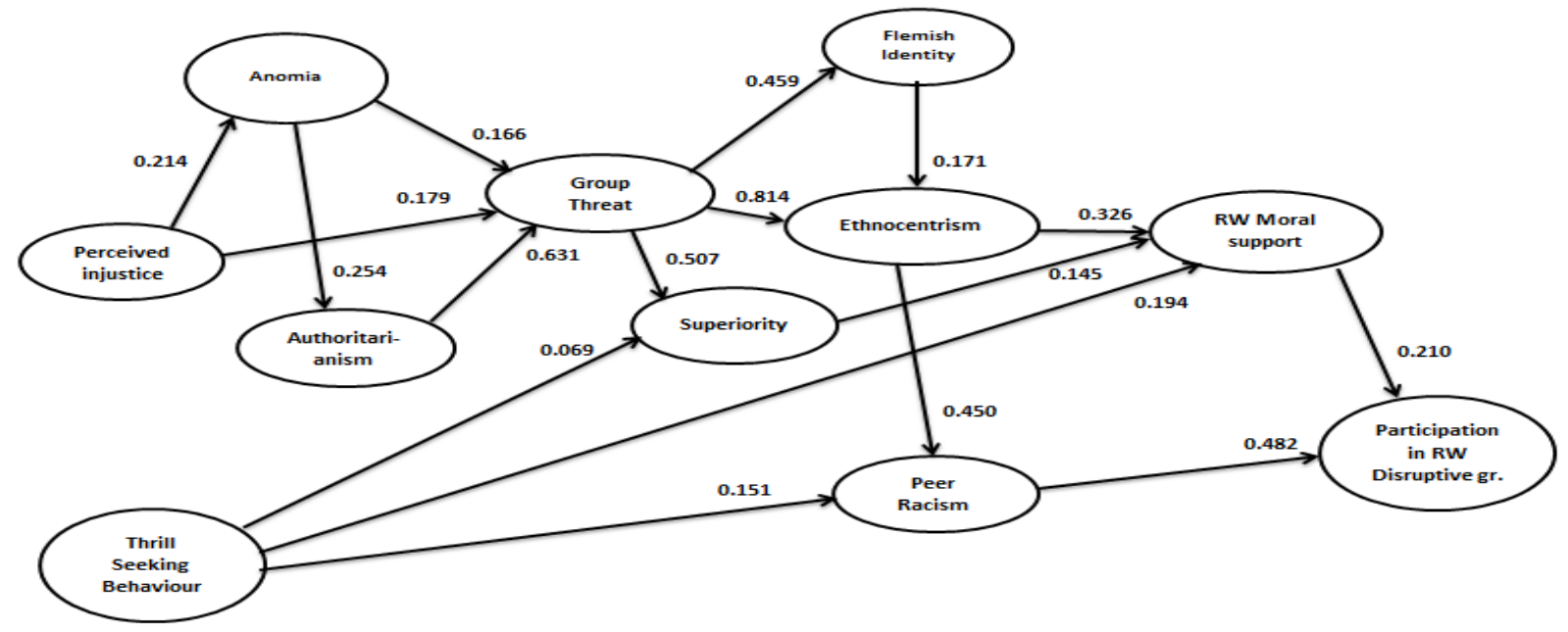

Fig. 2 Merged model for the explanation of participation in right-wing disruptive groups, RMSEA=0.067

Thrill-seeking behaviour also exhibits a direct effect on exposure to racist peers $(\beta=0.151)$, but not on participation in a right-wing disruptive group. Interestingly, there is no direct relationship between moral support for right-wing extremism and exposure to peer racism. In line with a key hypothesis of self-control theory, thrill-seeking behaviour is a common cause. There are only two direct effects on participation in a right-wing disruptive group: moral support for right-wing extremism (log-odds: 0.210) and exposure to racist peers (log-odds= 0.482). The integrative model has an acceptable model fit (= RMSEA 0.067).

\section{Discussion and conclusion}

Based on the results it has been shown that right-wing disruptive group participation partially stems from perceived injustice, group threat, authoritarianism and anomia. These factors may trigger feelings of superiority, Flemish identity and ethnocentrism, especially ethnocentrism plays a major role in further translating the aforementioned strains into moral support for right-wing extremism. Moral support for right-wing extremism and exposure to peer racism have a direct effect on right-wing disruptive group participation. Thrill-seeking behaviour is important as an additional exogenous mechanism: it affects both moral support for right-wing authoritarianism and exposure to racist peers. It cannot be denied that there is, at least partial, overlap between mechanisms or paths that lead to right-wing disruptive group participation. 
While this study revealed that this was the case for right-wing extremism, it is not known if such a model would be applicable to the study of religious Islamism extremism and left-wing extremism. Future studies should try to get insight in the general character of these mechanisms.

The present study has some limitations to take into account. First of all, this theoretical framework can only account for a part of the variation of youth's participation in right-wing disruptive groups. The theoretical framework is thus incomplete. We have identified direct effects of moral support for right-wing extremism and exposure to peer racism. Future research should pay attention to the relationship between right-wing extremism and the commitment of acts of hate-crime.

Second, our theoretical model has been applied to explain individual differences in right-wing disruptive group participation among students. Future research should investigate to what extent the model also applies to the explication of in right-wing disruptive group participation in adults and in non-student populations. The study is cross-sectional and therefore not optimal for making sure causal inferences as causes and effects are measured simultaneously. Finally we need to take into account that our results are based on a large-scale web survey. It is unclear to what extent our results are biased by this method of data collection.

However, our findings are consistent with a small but growing number of studies that empirically document the importance of fair treatment and discrimination as sources of rightwing extremism. Research into the domain of political violence is important not only for the development and evaluation of criminological theories, but also within the framework of prevention of political violence. Or, as Bouhana and Wikström (2010) have argued: if we cannot properly explain why and how people come to commit acts of violent extremism, we have little ground from which to develop effective preventive strategies.

\section{References}

Adorno, T. W., Levinson, D. J., Horkheimer, M., Aron, B., \& Frenkel-Brunswik, E. (1950). The authoritarian personality. New York (N.Y.): Harper and brothers.

Agnew, R. (2006). Pressured into crime: An overview of general strain theory: Oxford University Press, USA.

Agnew, R. (2011). Revitalizing merton: General strain theory. The origins of American criminology, $16,137$.

Akers, R. L. (1998). Social structure and social learning. Los Angeles: Roxbury.

Altemeyer, B. (1981). Right-wing authoritarianism: University of Manitoba Press Winnipeg.

Altemeyer, B. (1988). Enemies of freedom: Understanding right-wing authoritarianism: Jossey-Bass. 
Altemeyer, B. (1998). The other "authoritarian personality". Advances in experimental social psychology, 30, 47-92.

Antonaccio, O., \& Tittle, C. R. (2008). Morality, self-control, and crime*. Criminology, 46(2), 479510.

Bernard, T. J., \& Snipes, J. B. (1996). Theoretical integration in criminology. Crime and justice, 301348.

Bjørgo, T. (1997). Racist and right-wing violence in Scandinavia : patterns, perpetrators, and responses. Leiden: s.n.

Bjørgo, T. (2002). Exit Neo-Nazism: Reducing Recruitment and Promoting Disengagement from Racist Groups. Norwegian Institute of International Affairs (NUPI) working papers (627). .

Blumer, H. (1958). Race prejudice as a sense of group position. Pacific Sociological Review, 3-7.

Boijen, R. (1998). Leger (Vol. 3): Lannoo.

Bottoms, A. E. (2002). Morality, crime, compliance and public policy. Paper presented at the Ideology, Crime and Criminal Justice: A Symposium in Honour of Sir Leon Radzinowizs.

Bouhana, N., \& Wikström, P.-O. H. (2010). Theorizing Terrorism: Terrorism as Moral Action. Contemporary Readings in Law and Social Justice(2), 9-79.

Bruinsma, G. J. N. (1992). Differential association theory reconsidered: An extension and its empirical test. Journal of Quantitative Criminology, 8(1), 29-49.

Bursik, R., \& Grasmick, H. G. (1993). Neighborhoods and crime: The dimensions of effective community control: Lexington Books New York.

Burton, V. S., Cullen, F. T., Evans, T. D., Alarid, L. F., \& Dunaway, R. G. (1998). Gender, selfcontrol, and crime. Journal of Research in Crime and Delinquency, 35(2), 123-147.

Coffé, H. (2005). The adaptation of the extreme right"s discourse. Ethical Perspectives, 12(2), 205230.

Cohrs, J. C., \& Ibler, S. (2009). Authoritarianism, threat, and prejudice: An analysis of mediation and moderation. Basic and Applied Social Psychology, 31(1), 81-94.

Decker, S. H., \& Weerman, F. M. (Eds.). (2005). European street gangs and troublesome youth groups. AltaMira Press.

Decker, S. H., \& Pyrooz, D. C. (2015). "I'm down for a Jihad": How 100 Years of Gang Research can inform the Study of Terrorism, Radicalization and Extremism. Perspectives on Terrorism, $9(1)$

Doosje, B., Loseman, A., \& van den Bos, K. (2013). Determinants of radicalization of Islamic youth in the Netherlands: Personal uncertainty, perceived injustice, and perceived group threat. Journal of Social Issues, 69(3), 586-604.

Elliott, D. S., Ageton, S. S., \& Canter, R. J. (1979). An integrated theoretical perspective on delinquent behavior. Journal of Research in Crime and Delinquency, 16(1), 3-27.

Esbensen, F.-A., \& Weerman, F. M. (2005). Youth Gangs and Troublesome Youth Groups in the United States and the Netherlands A Cross-National Comparison. European Journal of Criminology, 2(1), 5-37.

Esbensen, F. A. (2010). Youth violence: Sex and race differences in offending, victimization, and gang membership. Temple University Press.

Esbensen, F. A., \& Maxson, C. L. (Eds.). (2011). Youth gangs in international perspective: results from the Eurogang program of research. Springer Science \& Business Media.

Goodwin, M., Ramalingam, V., \& Briggs, R. (2012). The New Radical Right: Violent and NonViolent Movements in Europe. In I. F. S. Dialogue (Ed.), (pp. 57).

Gurr, T. R. (1970). Why Men Rebel: Princeton: Princeton University Press.

Hagan, J., Merkens, H., \& Boehnke, K. (1995). Delinquency and disdain: Social capital and the control of right-wing extremism among East and West Berlin youth. American Journal of Sociology, 1028-1052.

Hedström, P. (2005). Dissecting the social: On the principles of analytical sociology: Cambridge University Press Cambridge.

Hedström, P., \& Bearman, P. (2009). The Oxford handbook of analytical sociology: Oxford University Press.

Heitmeyer, W. (2003). Right-wing extremist violence. In W. Heitmeyer \& J. Hagan (Eds.), International handbook of violence research (pp. 2 v.). Dordrecht: Kluwer academic. 
Hirschi, T. (1969). Causes of delinquency. California: University of California Press.

Hirschi, T., \& Gottfredson, M. R. (1990). A general theory of crime: Stanford University Press.

Hope, T. L., \& Damphousse, K. R. (2002). Applying self-control theory to gang membership in a nonurban setting. Journal of Gang Research, 9(2), 41-61.

Horgan, J. (2005). The psychology of terrorism. Oxon, New York: Routledge.

Jenkins, J. C., \& Gottlieb, E. E. (2007). Identity conflicts and their regulation: an introduction: Transaction Publishers.

Kimmel, M. (2007). Racism as adolescent male rite of passage. Journal of Contemporary Ethnography, 36(2), 202-218.

Kissner, J., \& Pyrooz, D. C. (2009). Self-control, differential association, and gang membership: A theoretical and empirical extension of the literature. Journal of Criminal Justice, 37(5), 478487.

Klein, M. W., \& Maxson, C. L. (2006). Street gang patterns and policies. Oxford University Press.

Kornhauser, R. R. (1978). Social sources of delinquency: An appraisal of analytic models: University of Chicago Press Chicago.

Laub, J. H., \& Sampson, R. J. (2003). Shared beginnings, divergent lives: Delinquent boys to age 70: Belknap Press.

Liska, A. E., Krohn, M. D., \& Messner, S. F. (1989). Strategies and requisites for theoretical integration in the study of crime and deviance Theoretical integration in the study of deviance and crime: Problems and prospects (pp. 1-19). Albay: State University of New York.

Maxson, C. L., \& Klein, M. (1995). Investigating gang structures. Journal of Gang Research, 3(1), 3340.

Michael, G. (2006). The enemy of my enemy: The alarming convergence of militant Islam and the extreme right: University Press of Kansas.

Mudde, C. (2002). The ideology of the extreme right: Manchester University Press.

Muthén, L. K., \& Muthén, B. O. (2012). Mplus User's Guide. Statistical Analysis with Latent Variables. Version 7. Los Angeles, CA: Muthén \& Muthén.

Pauwels, L. J. R., \& Svensson, R. (2013). Violent Youth Group Involvement, Self-reported Offending and Victimisation: An Empirical Assessment of an Integrated Informal Control/Lifestyle Model. European Journal on Criminal Policy and Research, 1-18.

Pauwels, L., \& Schils, N. (2014). Differential online exposure to radical content and political violence. Testing the relative strength of social learning and competing perspectives. Terrorism and Political Violence.

Pauwels, L., Brion, F., Schils, N., Laffineur, J., Verhage, A., De Ruyver, B., \& Easton, M. (2014). Explaining and Understanding the Role of Exposure to New Social Media on Violent Extremism. An integrative quantitative and qualitative approach. Ghent: Academia Press

Pauwels, L., Vettenburg, N., Gavray, C. \& Brondeel, R. (2011). Societal Vulnerability and Troublesome Youth Group Involvement: The Mediating Role of Violent Values and Low Self-Control. Journal of International Criminal Justice 21(3) 283-296.

Pennings, P., \& Brants, K. (1985). Rechts-extreme jongeren: theorie en praktijk van politiek randgedrag: Universiteit van Amsterdam; Vakgroep Collectief politiek Gedrag.

Pratt, T. C., \& Cullen, F. T. (2000). The empirical status of Gottfredson and Hirschi's general theory of crime: A meta-analysis. Criminology, 38(3), 931-964.

Quillian, L. (1995). Prejudice as a response to perceived group threat: Population composition and anti-immigrant and racial prejudice in Europe. American sociological review, 586-611.

Runciman, W. G. (1966). Relative deprivation \& social justice: study attitudes social inequality in 20th century England.

Sela-Shayovitz, R. (2012). The impact of globalization, migration, and social group processes on neoNazi youth gangs Youth Gangs in International Perspective (pp. 211-223): Springer.

Srole, L. (1956). Social integration and certain corollaries: An exploratory study. American sociological review, 21(6), 709-716.

Stams, G. J., Brugman, D., Deković, M., van Rosmalen, L., van der Laan, P., \& Gibbs, J. C. (2006). The moral judgment of juvenile delinquents: A meta-analysis. Journal of abnormal child psychology, 34(5), 692-708. 
Stephan, W. G., Boniecki, K. A., Ybarra, O., Bettencourt, A., Ervin, K. S., Jackson, L. A., . . Renfro, C. L. (2002). The role of threats in the racial attitudes of Blacks and Whites. Personality and Social Psychology Bulletin, 28(9), 1242-1254.

Svensson, R., Pauwels, L., \& Weerman, F. M. (2010). Does the effect of self-control on adolescent offending vary by level of morality? A test in three countries. Criminal Justice and Behavior, 37(6), $732-743$.

Tajfel, H. T., \& Turner, J. C. (1974). The social identity theory of intergroup behavior. Psychology of Intergroup Relations. Nelson-Hall, Chicago. Págs, 7-24.

Thornberry, T. P., Krohn, M. D., Lizotte, A. J., \& Chard-Wierschem, D. (1993). The role of juvenile gangs in facilitating delinquent behavior. Journal of Research in Crime and Delinquency, 30(1), 55-87.

Van der Valk, I., \& Wagenaar, W. (2010). Monitor Racisme \& Extremisme : The extreme right: Entry and exit Amsterdam: Amsterdam University Press.

Van Hellemont, E. (2013). Presentation of Documentar'Biso': Black African Gangs in Brussels. status: published.

Vettenburg, N., Gavray, C., Brondeel, R., Pauwels, L.J.R.. (2013). Societal vulnerability and adolescent offending: The role of violent values, self-control and troublesome youth group involvement. European Journal of Criminology, 10 (4): 444-461.

Warr, M. (2002). Companions in crime: The social aspects of criminal conduct: Cambridge University Press.

Watts, M. W. (2001). Aggressive youth cultures and hate crime. American Behavioral Scientist, 45(4), 600-615.

Whitley, B. E., \& Ægisdóttir, S. (2000). The gender belief system, authoritarianism, social dominance orientation, and heterosexuals' attitudes toward lesbians and gay men. Sex Roles, 42(11), 947967.

Wikström, P. H., \& Butterworth, D. A. (2006). Adolescent crime. Individual differences and lifestyles. Devon: Willan Publishing.

Wikström, P.-O. H. (2010). Explaining crime as moral actions Handbook of the Sociology of Morality (pp. 211-239): Springer. 